Article

\title{
More Than a Potential Hazard-Approaching Risks from a Social-Ecological Perspective
}

\author{
Carolin Völker ${ }^{1,2, *}$, Johanna Kramm ${ }^{1, *}$, Heide Kerber ${ }^{1}$, Engelbert Schramm ${ }^{1,2}$, \\ Martina Winker ${ }^{1}$ and Martin Zimmermann ${ }^{1}$ \\ 1 ISOE-Institute for Social-Ecological Research, 60486 Frankfurt/Main, Germany; kerber@isoe.de (H.K.); \\ schramm@isoe.de (E.S.); winker@isoe.de (M.W.); zimmermann@isoe.de (M.Z.) \\ 2 Senckenberg Biodiversity and Climate Research Centre (BiK-F), 60325 Frankfurt/Main, Germany \\ * Correspondence: voelker@isoe.de (C.V.); kramm@isoe.de (J.K.)
}

Received: 30 January 2017; Accepted: 27 May 2017; Published: 26 June 2017

\begin{abstract}
Risks have been classically understood as a probability of damage or a potential hazard resulting in appropriate management strategies. However, research on environmental issues such as pollutants in the aquatic environment or the impacts of climate change have shown that classical management approaches do not sufficiently cover these interactions between society and nature. There have been several attempts to develop interdisciplinary approaches to risk that include natural as well as social science contributions. In this paper, the authors aim at developing a social-ecological perspective on risk by drawing on the concept of societal relations to nature and the model of provisioning systems. This perspective is used to analyze four cases, pharmaceuticals, microplastics, semicentralized water infrastructures and forest management, with regard to risk identification, assessment and management. Finally, the paper aims at developing a perspective on risks which takes into account non-intended side-effects, system interdependencies and uncertainty.
\end{abstract}

Keywords: pharmaceuticals; microplastics; semicentralized water infrastructures; forest management; provisioning system; normal operation

\section{Introduction}

The detection of anthropogenic micropollutants in the water cycle or the environmental changes caused by climate change are examples of current risks, which point to the relation between society and nature, as well as to the relational character of risk; put in a simple way, this is a relation of cause and (often undesired or adverse) effect. The term "risk" enjoys great popularity, though at the same time it comes with a variety of definitions [1]. A definition often referred to says: the "term 'risk' denotes the likelihood that an undesirable state of reality (adverse effects) may occur as a result of natural events or human activities" [2] (p. 50). A distinction is made between risk and hazard. While hazards are defined as a potential source of harm (e.g., toxicity of a chemical substance), a risk emerges when there is a likelihood that the hazard will produce harm [2]. The technocratic understanding is an equation involving the possibility of an adverse effect and the potential damage, while emphasis in the social sciences, for instance is laid on perception and decision-making [3]. Different concepts and theories of risk have been developed. They vary from those found in cultural studies and the social sciences, which embrace a constructivist approach to nature, and the technical and natural sciences which adopt an objectivist approach (for an overview see $[4,5]$ ). Social science theories comprise system theory following Luhmann, which stresses ways of risk communication [6], cultural theories working on cultural assumptions on risk and risk perception [7], and psychological theory centering around subjective judgment of the extent and character of risks [8]. In the natural sciences, for instance ecotoxicology, environmental risk assessment considers a cause deriving from a toxic substance (e.g., chemical, which has effects on an organism). An "environmental risk" is then a product 
of exposition, toxicity and sensitivity. Classical risk analysis calculates the possibility of an adverse event and the potential damage, for instance an assessment of the ecotoxicity of hazardous substances based on dose-response relationships. Similar accounts for engineering sciences. Here, risks are calculated for socio-technical systems such as energy or water infrastructures which are susceptible to hazards.

There has been a debate in risk research on how to consider society-nature interactions in risk analysis $[1,9]$. This paper takes up this debate and suggests a social-ecological perspective on risks which focuses on the interactions between society and nature. The concept of societal relations to nature [10] and the model of social-ecological systems (SES) as provisioning systems $[11,12]$ (Hummel et al. 2017 in this special issue) are used to characterize society-nature interactions. The aim of the paper is to elaborate a social-ecological perspective on risks by drawing on four case studies analyzed with the concepts of societal relations to nature and provisioning systems.

The next section gives an overview of the current risk research. The subsequent section introduces the four case studies and in a second step discusses them, deploying the analytical framework of provisioning systems. In a third section, aspects of the studies are discussed to develop conceptual notes on a social-ecological risk perspective. It is further discussed how this perspective helps to identify risk management strategies and how to govern risks.

\section{State of the Art: Risk and the Social-Ecological Perspective}

As outlined in the introduction, the conceptualization and the understanding of "risk" vary highly. A common and quite popular way of classifying different risk concepts has been a disciplinary ordering. Several reviews $[2,13,14]$, notably work by Ortwin Renn, have presented the concept as used in natural and technical sciences, economics, psychology and social and cultural studies.

Examples for technical and natural science concepts of risks comprise actuarial analysis of the insurance business, in which the expected value-an equation of the probability of an event multiplied by the insurance sum of the event-is the reference point; toxicological and epistemological risk assessments using causal models of risks to identify substances, like carbon monoxide or benzene, that may cause harm to humans or the environment [15] and probabilistic risk assessments which attempt to predict the probability of undesirable events within complex technical systems [16]. In sum, they "anticipate potential physical harm to human beings, cultural artefacts, or ecosystems, average these events over time and space, and use relative frequencies or estimated probabilities (observed or modelled) as a mean to specify likelihood" [2] (p. 52). These kinds of risk analyses are useful for identifying causes and predicting events with undesirable effects and therefore help decision-makers in accident management and emergency planning. They are important to improve safety of technical systems [2]. The technical and quantitative risk analyses have been subject to criticism from social sciences [14,17]. Among other critique, the objectivity of the identified risks is questioned and it is emphasized that risk analysis cannot be considered as "value-free scientific activity" [2] (p. 52). Furthermore, critics point to the subjective perceptions of people with under- or overestimating the probability of certain adverse events and the role of the media [18,19].

Renn clustered risk approaches in social sciences along two axes from individualistic to structuralist approaches and from constructivist to realistic ones [2]. In this taxonomy, he classifies postmodern theory [20], cultural theory [21] and Luhmann's system theory [22] (constructivist and structuralist), critical theory [23] (realistic and structuralist), rational choice theories [24] (realistic and individualistic) and theories of reflexive modernization [25] (individualistic and constructivist). Overall, the approaches have in common that risks are related to decision-making under uncertainty [26].

Aven [27] (p. 34) suggests to overcome a classification of risk which is based on "objective reality" vs. "societal phenomenon". He argues for a new way of classifying risks and develops six risk perspectives based on six development paths. By this, he develops perspectives which are crossing scientific disciplines, but he remarks that the "risk perspective chosen strongly influences 
the way risk is analyzed and hence it may have serious implications for the risk management and decision making" [27] (p. 42). There have been further attempts to develop an integrative approach to risk [28]. The discussed approaches comprise the social amplification of risk concept [18,29], the risk types according to WBGU [30] and finally the IRGC's risk governance framework [31]. The model of the International Risk Governance Council (IRGC), which in contrast to the Red Book model to the co-evolutionary approach [32] integrates the assessment sphere, the management sphere and the communication sphere and by this accommodates the technical/natural science and the social dimensions of risk.

This paper elaborates a further perspective, which builds on the integrative aspects of risk research and at the same time takes into account the society-nature interactions. For developing a social-ecological risk perspective, we draw therefore on the concept of societal relations to nature [10] and the model of social-ecological systems (SES) as provisioning systems [11,12].

The concept of "societal relations to nature" frames society-nature interactions in a non-dualistic way as patterns of regulation aiming at the reproduction of societies. Particular sets of characteristic societal relations to nature can be represented in a provisioning system [12] (Hummel et al. 2017 in this issue). Provisioning systems are "developed [and regulated] by societies [to] provide goods and services such as food, water, or energy [and] based on ecosystems and their geophysical environments" [11] (p. 11). Resource usage in a provisioning system is regulated by practices, knowledge, technologies and institutions. This regulation of provisioning systems can cause intended and non-intended effects on ecological and biophysical processes and structures (ecosystems or human health), as well as on social processes and structures (economies, etc.) within a system and on other provisioning systems [11]. These effects can cause feedback processes that might call for new decisions, or have effects on cultural and social processes. Such feedback processes can be immediate or buffered; they can be anticipated with a proactive reaction, or non-anticipated with a reactive response, and they can take place within a system as well as affecting other systems. Thus, these systems are linked. Taking feedback processes and unintended effects into account, it is important to be aware that every action associated with risk management and problem solving can cause non-intended effects and risks; this is called self-referentiality [33].

Who or what is "at risk"? From a social-ecological perspective, societies as well as ecosystems can be at risk, ranging from "material things", such as infrastructure, buildings, etc., to humans and non-humans, like organisms and whole ecosystems, to social-ecological systems, like the operation of a provisioning system. The causes of risks lie mostly in human activities, since most bio-physical processes and natural resources are regulated by societies [11].

\section{Social-Ecological Perspective in Risk Research}

The four case studies were taken from projects conducted at the ISOE-Institute for Social-Ecological Research and were selected because they all address interactions between society and nature and represent a broad spectrum of risk themes. The case studies are on (a) pharmaceutical residues in the aquatic environment, (b) microplastics in the aquatic environment, (c) semicentralized water infrastructures, and (d) forest management. The case of pharmaceuticals was derived from studies conducted within several projects, including start (2005-2008) and SAUBER+ (2011-2015), the microplastics example is covered in the project PlastX (2016-2021), semicentralized water infrastructures are dealt with in the project Semizentral (2013-2017), and forest management within the BiK-F project (2008-2021).

The cases were analyzed by identifying (1) possible negative effects, (2) the affected (provisioning) systems, and (3) the causes of the potential effects. The following questions were used as guide for discussing the results:

What is the scope of the negative effects and how might they affect other linked systems?

How do these systems interplay?

Which risk management strategies exist and do they produce competing interests? 


\subsection{Pharmaceutical Residues in the Aquatic Environment}

\subsubsection{Case Outline}

First detections of pharmaceutical residues in the aquatic environment date back to the 1970s [34-37]. Nowadays, pharmaceutical residues can be detected in nearly all compartments of the water cycle. Their existence has been demonstrated in surface waters, seawaters, groundwater and even at the nano-level in drinking water in a few cases [38,39].

The original cause of pharmaceutical residues in the water cycle lies in human medical care: Some pharmaceutical substances used for human therapy are only slightly transformed by the human body, excreted, and afterwards not completely eliminated in wastewater treatment plants (WWTPs). Finally they are discharged into the aquatic environment. Besides urban WWTPs, discharges from manufacturing, animal husbandry, and aquacultures are further emission pathways [40].

The introduction of some of these pharmaceuticals into the environment poses a risk to aquatic wildlife, since negative effects have been demonstrated at environmentally relevant concentrations, for instance in the case of endocrine disruptors such as steroid hormones [39]. Uncertainty exists regarding the risks for whole ecosystems due to knowledge gaps in respect of the mixture toxicity of pharmaceuticals, as well as chronic and subtle effects that might have consequences at the population level [39]. Acute effects for human beings due to the occurrence of pharmaceutical residues in drinking water do not exist; the daily intake via drinking water is far from reaching therapeutic doses [41]. However, since pharmaceuticals are continuously released into the environment ("pseudopersistent"), serving to sustain long-term exposure, precautionary measures are discussed to reduce risks in advance. In most cases, these measures comprise end-of-pipe solutions, e.g., modifications of WWTPs in order to improve removal efficiencies.

\subsubsection{Risks as Side-Effects of Normal Operation}

The social-ecological perspective on the issue of pharmaceutical residues in the aquatic environment clearly points to a risk involving the "water services" provisioning system as pharmaceutical residues are detectable in aquatic ecosystems as well as in drinking water. The "water services" provisioning system comprises the disposal of wastewater, the connected aquatic ecosystems, and the water supply, including drinking water. As wastewater constitutes the risk-producing part of the provisioning system, measures to prevent the emission of pharmaceuticals predominantly focus on WWTPs and advanced treatment technologies.

However, by including interconnected provisioning sytems as well, the mode of risk production comes into focus: in the case of the "water services" provisioning system, the risk for the aquatic ecosystem and consequently for human health is produced by wastewater emission but it originates from the use of pharmaceuticals to treat and prevent diseases, and hence from the provisioning system "human health care" (Figure 1). What is striking is the fact that the use, excretion and disposal of pharmaceuticals is organized in a way that these agents are intentionally released into the water cycle. Consequently, the health care system in its "normal mode of operation" produces a risk for the "water services" provisioning system [42].

It becomes clear that measures within this provisioning system, such as an additional treatment step in wastewater treatment plants, are not enough. Such measure must be complemented by innovations in the health care system to reduce the load of pharmaceuticals in water bodies. This means that as a part of precautionary measures, the "human health care" provisioning system needs to be readjusted. If possible, the consumption of pharmaceuticals should be reduced, and supported by measures such as different prescribing practices and disease prevention, proper handling of pharmaceuticals, and the development of environmentally friendly pharmaceuticals [43]. 


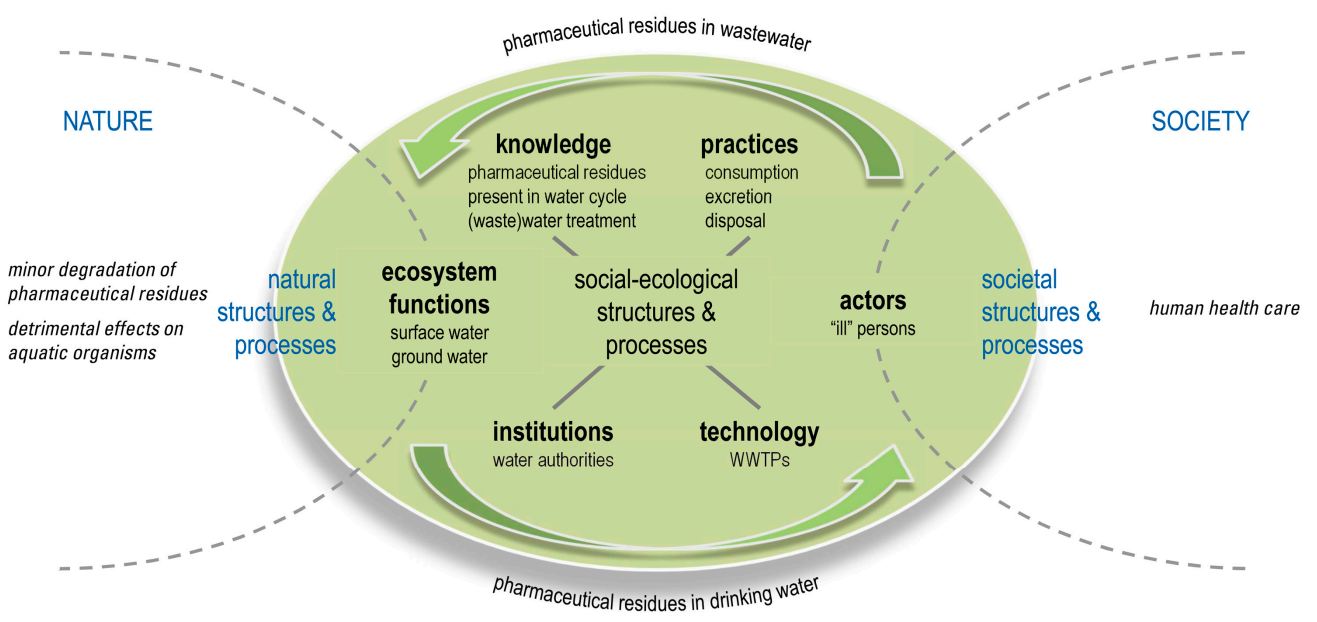

Figure 1. Impact of human health care on the "water services" provisioning system (own draft based on [11]).

In conclusion, the social-ecological perspective does not consider extreme events or disasters in order to develop risk management strategies. By drawing on the concept of provisioning systems, risks are discovered which arise through "processes of self-endangerment brought about by modern, highly interconnected societies" [42] (p. 357). Therefore, this analytical perspective leads to risk management strategies which target the reorganization of the involved provisioning systems [42].

\subsection{Microplastics in the Aquatic Environment}

\subsubsection{Case Outline}

The term "microplastics" emerged in the 2000s to describe small plastic fragments detected in seawaters since the 1970s [44]. Meanwhile, a rising number of studies has discovered the vast extent of microplastic pollution reaching from deep-sea sediments to freshwater environments $[45,46]$.

The causes of microplastic pollution are as variable as the material types introduced into the environment. So-called "primary" microplastics are manufactured for their application in specific products, such as cosmetics or air-blasting technology, but they also involve virgin plastic production pellets [47]. These primary microplastics mainly enter the aquatic environment via domestic and industrial WWTPs [48]. "Secondary" microplastics derive from the breakdown of larger plastic items, such as plastic waste introduced into the environment, but also chemical fibers washed from fabrics, or tire dust from road traffic discharged by WWTPs [47]. Secondary microplastics are considered to be the main source of microplastic pollution [49].

Uncertainties exist regarding the risks these microplastic particles pose to the ecosystems where they persist [50]. Studies have shown that microplastics are ingested by various aquatic organisms including organisms that play a role in human consumption (such as shellfish and fish) [51,52]. So far, biological effects have only been detected in the laboratory at particle concentrations that have limited environmental relevance [53]. Furthermore, risk assessment is complicated, as microplastics might also transfer plastic-associated chemicals (such as additives or adsorbed pollutants) to organisms, with negative impacts on their health. Currently, researchers argue that the existing knowledge gaps are too large to properly assess the risks of microplastics for ecosystems [54]. The same holds true in respect of the risks for human health of microplastics-contaminated food [55]. Nevertheless, precautionary measures are discussed which mostly focus on primary microplastics. These measures comprise advanced wastewater treatment and regulatory approaches, such as a ban (in the United States) on microplastics in specific cosmetic products [56]. Furthermore, voluntary commitments have been made by plastic processing industries addressing zero pellet loss or phase-out of microplastics in cosmetics [56]. 


\subsubsection{Societal Significance of Risks}

The microplastics example shows some parallels to pharmaceutical residues in the water cycle. A chemical agent is introduced into aquatic ecosystems via WWTPs, involving the "water services" provisioning system. Microplastics from cosmetic products or fibers washed from fabrics also enter the environment as side effects of the normal wastewater processing strategy.

From a social-ecological perspective, the case of microplastics cannot be considered in isolation from plastic waste in a larger context, as the pathway via WWTPs accounts for only a relatively small amount of the pollution. As mentioned above, most plastic particles in the environment stem from the degradation of larger plastic waste. The origin of this plastic waste cannot be attributed to one specific provisioning system that produces the risk and can be readjusted. Since plastic products, for instance plastic packaging, are an integral part of modern societies, a variety of provisioning systems come into focus, ranging from food supply to human health care. These systems meet when it comes to the disposal of plastics and proper waste management. In this case, it can be argued that if the systems set up for correct disposal of plastics operated properly, plastics would not reach the environment in relevant amounts. However, the huge amount of plastics leaking into the environment worldwide throws doubts on the existence of "normal" operating waste management systems. It seems that the current mode, with its leakages, is the "normal" mode. Nevertheless, risk management strategies should include proper waste management, but also-and especially in countries which lack waste disposal systems-target the reorganization of the respective systems regarding sustainable production and consumption patterns to reduce the production of plastic waste.

However, the microplastics example shows further aspects which come into focus by adopting a social-ecological perspective. In this case, societal perception and the mobilization potential of the society are important drivers for risk management. So far, ecotoxicological studies have not been able to conclusively characterize the risk posed by microplastics to aquatic ecosystems due to the above-mentioned complex material characteristics. Despite the absence of clear scientific evidence, it is common sense in most societies that plastics should not end up in the environment. In many cases, there are aesthetic reasons for this, which have political, social, and economic consequences, for example when there is a risk of losing tourism revenues due to beaches littered with plastic debris [57-59]. Furthermore, the public debate, triggered by the media [60,61], centers around the potential abundance of microplastics in human food suggesting human health risks. These reports are only based on single observations, and as yet there is no evidence of negative effects on human health. Nevertheless, microplastics are perceived as a threat to the "food" provisioning system and thus to human health [62]. The social-ecological approach to the issue of microplastics in the aquatic environment considers both technical risk calculations, here the ecotoxicological approach, and the societal significance of the risk. This makes it possible to address the ecological and the social consequences. Moreover, communication processes involving public interest groups help to identify resilient strategies for coping with uncertainties and thus managing the risk [63].

\subsection{Semicentralized Water Infrastructures}

\subsubsection{Case Outline}

Technical innovations such as treatment and reuse of partial wastewater streams at their point of origin in combination with new management approaches result in radical innovations of the water infrastructure [64-67]. These concepts lead to a different design: decentralized or semicentralized components cause a higher flexibility due to a modular architecture and enable more options for water and energy reuse. Wastewater streams of different quality (e.g., blackwater from toilets and greywater from showers, sinks, kitchens, washing machines) can be treated separately by using dual sewers. In addition, greywater can be recycled to produce service water for toilet flushing or the irrigation of green space. Through this modular architecture, urban water services can be adjusted flexibly to 
rapidly growing (or shrinking) population numbers. Furthermore, the reuse of water (and heat or other resources) contributes to an efficient management of natural resources.

Water supply and disposal systems are categorized as critical infrastructures, i.e., they are essential for the functioning of a society and its economy. The vulnerability of novel infrastructures must be analyzed from this perspective, where vulnerability is understood as the susceptibility and resilience of the system's components to certain hazards [68]. The potential causes of a failure of the water infrastructure, or of parts of it, can be internal or external. They include natural hazards (heavy rainfall, floods, droughts, earthquakes) and human or technical failure (pipe bursts, sabotage). The failure of the water infrastructure, in turn, might endanger the users' health or surrounding ecosystems, for instance if the user has contact with contaminated service water, or if untreated wastewater is discharged into the environment.

Risk analyses for wastewater utilities are usually based on technical safety management. The probability of occurrence of potential hazards (threats) to the infrastructure is quantified based on statistical data or estimations. In addition, the damage to subjects of protection (e.g., users, technical infrastructure, ecosystems) is quantified in monetary terms. High probabilities of occurrence and high possible damage indicate a high level of risk and necessitate precautionary measures to prevent the predicted damage.

\subsubsection{Integrative Risk Assessment}

The case of semicentralized water infrastructures differs from the previous examples of pharmaceuticals and microplastics as it has a strong spatial dimension by focusing on a specific technological system. Furthermore, this system is already able to combat existing problems within the "water services" provisioning system, coping for instance with water scarcity by implementing improved water efficiency. The focus in this case is on the hypothetical risks posed by hazards, or a failure of interconnected provisioning systems, such as (drinking) water supply, electricity, or the disposal of food waste. The aim is to minimize risks which do not occur in the context of normal operation, but which are due to negative events which may have a natural origin (e.g., extreme weather, landslides) or a socio-technical one (e.g., vandalism, faulty connections). The hazards can be multiple and lie within the system itself (human or technical failure) or be exogenous (weather). At risk is the safe operation of the water infrastructure guaranteeing an adequate service water supply, as well as wastewater management, including safe discharge of the treated wastewater into the environment. In a worst case scenario, the effects may lead to a breakdown of the infrastructure, resulting in health hazards for the users due to an inadequate service water supply, and/or environmental pollution due to the disposal of wastewater which is untreated or inadequately treated.

To avoid these consequences, risk analyses serve to assess the vulnerability of the system to these hazards, and to take adequate measures for risk management. In addition to the conventionally applied risk assessment approach, the social-ecological approach integrates the interdependencies between the infrastructure and connected provisioning systems and ecosystems. By adopting this systemic perspective, differences in the appropriation of natural resources become apparent, since the semicentralized system is more resource efficient than conventional infrastructures, for example in terms of groundwater resources for (drinking) water supply purposes. Furthermore, the users become a significant part of the analysis. On the one hand, users might be influenced by malfunctioning of provisioning systems that are dependent on the functioning of the water infrastructure. On the other hand, the kind of usage (routines, usage patterns, misuse) influences the functioning of the infrastructure, which is why the users' practices and their handling of the water infrastructure are integrated into the analysis. The described integrative take on technological risk or vulnerability analysis hence contributes to a broader understanding of social-ecological interdependencies, and offers more promising options for action in respect of risk management. This approach also considers the diversity and complexity of the actors (e.g., users, operators, craftsmen), as well as their practices. 
Consequently, the actors do not have to adapt their actions to the infrastructure's requirements and its assigned management regime, but rather the water system is adjusted to the actors' needs and behavior.

\subsection{Sustainable Forest Management}

\subsubsection{Case Outline}

Central European forests play an important role in timber production, but also serve as a place for outdoor recreation, for regeneration of water, or as a protection against mudflows and rockfalls (in Alpine regions). Global climate change directly and indirectly affects the growth and productivity of Central European forests. Besides forest biome shifts, an immediate risk is the loss of forests at specific locations. If forest ecosystems are degraded, or even destroyed, their recultivation is challenging. Effects that point to this risk can already be observed in form of the destabilization of existing forests, for example in specific regions in Germany (Hessian Ried): oak forests have been severely depleted due to climate change, a lowering of the groundwater level, and cockchafer epidemics [69]. However, no reliable statements can be made on which of the observed effects were caused by climate change and which occurred due to silvicultural mistakes, excessive numbers of game animals, or other causes [70].

To date, Central European forests have mostly been cultivated at a profit. But in future, substantial declines in earnings caused by climate change are expected by forest economists [71]. Experts predict a decline in timber yields [71], as well as a decline in forest functions [72]. Because of the loss of retention functions offered by alluvial forests, residential areas near rivers are increasingly threatened by floods. And the regeneration of ground water is endangered when the soil loses its ability to retain water or to decompose contaminants, due to a loss of forest vegetation [73].

So far, risk management has focused on the reduction of operational risks of the forest enterprises [74]. Most foresters have decided on a "no-change" strategy because of their doubts whether active management is possible. Smaller numbers tend to follow a "trial and error" strategy, or to plant more climate resistant tree species [75]. Therefore, the challenge for forest policy and science is to identify the tree species with a predicted optimum yield in future [76].

\subsubsection{Integrative Management Approach}

The example of Central European forests also has a strong spatial dimension. In this case, forestry systems are at risk due to climate change, and risk management concentrates on their future cultivation. Drawing on the concept of provisioning systems, the described forestry systems represent a characteristic case of societal relations to nature. These forests have been cultivated for specific purposes for a long time, and provide specific ecosystem services, such as timber, provision of clean water and air, water retention and flood protection, but also cultural services, like space for recreation. If the functioning of these forestry systems fails, the connected provisioning systems which benefit from the ecosystem services provided will bear the consequences.

At the moment, the regional characteristics of climate change and subsequent effects on forests are difficult to predict. Nevertheless, climatic extremes (storms, droughts, torrential rains, frost events) are likely to occur more often in the future, and have been addressed in forestry practice, at least in Germany. In this regard, an adaptive management approach is pursued: forests are restructured by planting tree species which are less susceptible to environmental changes, including climate resistant species from North America such as the Douglas fir. However, this approach solely addresses economic losses for forest enterprises, as forest management concentrates on profit-yielding species and the ecosystem service "timber production" [74]. In contrast to forest practitioners, conservationists and recreational visitors demand sites with a portfolio of different trees. In this regard, an adaptive management strategy should consider how to maintain the diverse ecosystem services of forestry systems. The social-ecological approach embraces interconnected provisioning systems and, therefore, the "multifunctionality" of forests. This approach thus addresses the needs and demands of linked provisioning systems and seeks to negotiate between the different stakeholders involved. Moreover, 
a tree portfolio maintaining the multifunctionality of forests for provisioning systems simultaneously addresses the functioning of the ecosystem. The social-ecological perspective, therefore, helps to develop management practices that are sustainable and maintain the characteristic societal relations to these ecosystems.

\section{Discussion}

In accordance with newer approaches to risk governance [18,29-31], the social-ecological perspective aims at integrating technical and social contributions to risk assessment, evaluation, and management in order to comprehensively address complex environmental issues. However, by drawing on the concepts of societal relations to nature and provisioning systems, the social-ecological perspective focuses on specific aspects which are outlined in the following:

- The social-ecological perspective does not consider natural hazards such as earthquakes or volcanic events that might have catastrophic effects and require crisis management. The same holds true for risks that can be understood as "normal accidents" (cf. [77]) but have solely social implications, for instance working conditions or health risks such as smoking. In social-ecological research, the focus is set on risks that arise through specific society-nature interactions which are regulated in a non-sustainable way and affect ecological as well as social processes and structures. By framing risks as a product of the "normal" operation of a provisioning system, the analytical perspective focuses on the mode of risk production and, therefore, leads to the conception that the involved provisioning systems need to be reorganized, as shown by the case of pharmaceutical residues in the water cycle. The social-ecological analysis includes the fact that risks can be transboundary, traveling across the border of risk producing systems into other linked (provisioning) systems [78]. Thus, these risks can be characterized by a specific vibrancy which affects other linked entities or systems, as demonstrated in the case of pharmaceuticals and microplastics. On the one hand, these linkages result from a physical connection of the involved provisioning systems, like the connection of the health care system and the "water services" system through wastewater flows. On the other hand, these linkages emerge through social processes (like communication, practices) affecting different social, political and economic spheres, for instance societal aversion to beached plastic debris inducing income losses in the tourism sector. Thus, the social-ecological approach includes both so-called objective approaches, trying to assess risks with probability assessments, and constructivist approaches that consider how the risk is socially constructed and perceived.

- The social-ecological perspective takes into account that risk management approaches can always have (non-intended) side effects and affect other linked entities or systems, as shown in the cases of novel water infrastructures and forest management. In this regard, a social-ecological approach integrates interdependencies of involved systems with the respective stakeholders from the beginning. Thus, knowledge from the technical and natural sciences is combined with knowledge from the social sciences on everyday practices, for instance the behavior of users in the case of novel water infrastructures.

From a social-ecological perspective, the starting point of risk analysis depends on the guiding question (this question might come up within a scientific community or from discussions in society); the question can focus on a single agent and its potential impacts on a system (Figure 2a) or on a system (with its subsystems) that is at risk due to several stressors (Figure 2b). In the case of pharmaceuticals and microplastic particles, the focus is on specific chemical substances introduced into the aquatic environment resulting in certain risks for the ecosystems involved. By contrast, the cases of water infrastructures and forests focus on specific systems that are at risk due to natural and anthropogenic causes. In the first case (Figure 2a), the analysis aims at making a hazard assessment of the substance and its possible reduction and removal, while in the second case (Figure $2 b$ ) it is centered on adaptation 
of the system's functions to cope in an enhanced way with its stressors. Further perspectives may evolve by considering other cases.

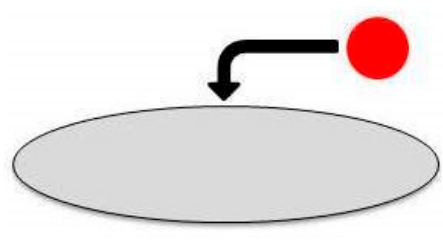

(a)

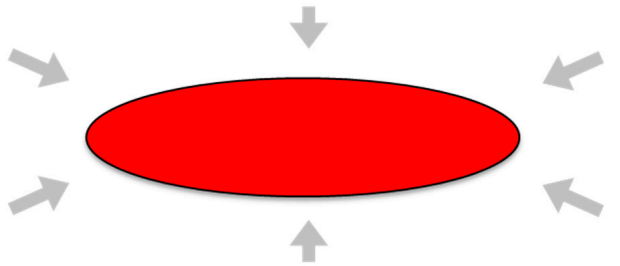

(b)

Figure 2. Different foci for risk analysis. (a) Focus on a single agent and its potential impact on a system; (b) focus on a system that is at risk due to several stressors.

As argued above, it is important to consider linkages and interdependencies in the social-ecological system. In the first case, it is important to analyze the system from which the agent derives, i.e., the causing or risk producing system. Furthermore, effects of the agent on other systems are crucial for understanding the cause-effect relationships in depth. In the second case, understanding the interdependencies of related systems is imperative for integrated management, as shown by the interplay of groundwater resources, timber production, space for human recreation, etc., in the case of forest management.

In accordance with other integrative risk governance approaches [28,79], the widening of the analytical focus subsequently has implications for management of the identified risks. These integrative management approaches include the technical as well as the social dimension of risks [79]. Table 1 gives an overview of risk management strategies frequently applied to the cases outlined in this article, and their extension through an integrated, social-ecological perspective.

Table 1. Approaches to risk management.

\begin{tabular}{|c|c|c|}
\hline & $\begin{array}{c}\text { Frequently Applied } \\
\text { Management Approaches }\end{array}$ & $\begin{array}{c}\text { Management Approaches Derived from a Social-Ecological } \\
\text { Analytical Framework }\end{array}$ \\
\hline $\begin{array}{l}\text { Pharmaceutical } \\
\text { residues }\end{array}$ & $\begin{array}{l}\text { Advanced wastewater } \\
\text { treatment (end-of-pipe } \\
\text { solution) }\end{array}$ & $\begin{array}{l}\text { Integrative sustainability policies [43] including } \\
\text { - } \quad \text { a transformation of the health care system (improved } \\
\text { doctor-patient communication, preventive measures to } \\
\text { reduce the prevalence of risk factors related to certain } \\
\text { diseases, etc.) } \\
\text { encouragement for the introduction of environmentally } \\
\text { friendly pharmaceuticals } \\
\text { - measures in the area of environmental engineering }\end{array}$ \\
\hline Microplastics & $\begin{array}{l}\text { Regulations and measures } \\
\text { focusing on primary } \\
\text { microplastics }\end{array}$ & $\begin{array}{l}\text { Integrative strategies for sustainable production, usage and } \\
\text { disposal of plastics including } \\
\text { - } \quad \text { transformations of practices involving short-lived plastic } \\
\text { products in various provisioning systems } \\
\text { - } \quad \text { the implementation of measures towards a } \\
\text { circular economy } \\
\text { - } \begin{array}{l}\text { encouragement for the introduction of environmentally } \\
\text { friendly polymers }\end{array}\end{array}$ \\
\hline $\begin{array}{l}\text { Semicentralized water } \\
\text { infrastructures }\end{array}$ & $\begin{array}{l}\text { Safe operation of the system by } \\
\text { technical safety management }\end{array}$ & $\begin{array}{l}\text { Widening the scope to the social and ecological environment } \\
\text { of the technical system by taking into accountthe } \\
\text { - } \quad \text { actors of the system and their behavior } \\
\text { - interdependencies with connected provisioning systems } \\
\text { - impacts on the appropriation of natural resources }\end{array}$ \\
\hline Forest management & $\begin{array}{l}\text { Adaptive management } \\
\text { focusing on timber production }\end{array}$ & $\begin{array}{l}\text { Adaptive management considering the "multifunctionality" of } \\
\text { forests by } \\
\text { - } \quad \text { identifying a diverse tree portfolio able to maintain } \\
\text { multiple ecosystem functions } \\
\text { - } \quad \text { integrating the needs and demands of different } \\
\text { stakeholders and required ecosystem services }\end{array}$ \\
\hline
\end{tabular}


As in the case of pharmaceuticals, but also in the other cases, the social-ecological approach to these issues aims at transforming the "normal" operation mode of provisioning systems. This is certainly a challenging endeavor, because it is not possible to apply this type of management within a single provisioning system. A comprehensive management approach is necessary which takes all linked systems into account, especially if the system's transformation is dependent on simultaneous measures in other systems. As shown in Table 1 for the case of pharmaceuticals, a transformation of the health care system is desirable, allowing for synergies like a reduction of pharmaceuticals in water bodies and improvements in the field of disease prevention. If the dynamics in coupled systems are not sufficiently addressed, risk management approaches will remain one-dimensional and will only deal with the symptoms (cf. $[43,73])$. But a "multifunctional" perspective, as described in the case of forest management, can make it possible to identify risks for other, linked provisioning systems [80].

A key challenge of managing risks is dealing with uncertainty [81]. Uncertainty arises because, as shown in the case studies, the risks are often complex and characterized by a lack of knowledge on cause-effect linkages regarding time, scope and spatiality. A high degree of uncertainty, in turn, impedes the development of effective risk management strategies. Therefore, risk assessment aims to resolve these uncertainties by closing the existing knowledge gaps. In most cases, however, a knowledge base that eliminates any uncertainty can never be achieved. For instance, in the cases of pharmaceuticals and microplastics, it is practically impossible to gain scientific evidence showing the effects on different organisms of every possible combination of substances, dosages, exposure duration, etc. [50]. More scientific evidence broadens the knowledge base, but some uncertainty will always remain (see Table 2). Furthermore, more scientific research may reveal new questions and non-knowledge, leading to an increased complexity and even more uncertainty. Therefore, the management of risks is always accompanied by uncertainty, and it is not necessary to understand all possible cause-effect linkages in order to develop solution strategies, but rather the question is how much scientific knowledge is necessary for legitimizing informed action.

Table 2. Different types of uncertainty encountered within the case studies.

\begin{tabular}{|c|c|c|}
\hline & Reason for Uncertainty & Degree of Uncertainty \\
\hline Pharmaceutical residues & $\begin{array}{l}\text { Lack of knowledge on subtle, } \\
\text { chronic, and mixture effects }\end{array}$ & $\begin{array}{l}\text { Knowledge base concerning specific } \\
\text { adverse effects can be broadened, but never } \\
\text { entirely be established. Some uncertainty } \\
\text { will remain. }\end{array}$ \\
\hline Microplastics & $\begin{array}{l}\text { Lack of knowledge on } \\
\text { biological effects }\end{array}$ & $\begin{array}{l}\text { Knowledge base concerning specific } \\
\text { adverse effects can be broadened, but never } \\
\text { entirely be established. Some uncertainty } \\
\text { will remain. }\end{array}$ \\
\hline $\begin{array}{l}\text { Semicentralized water } \\
\text { infrastructures }\end{array}$ & $\begin{array}{l}\text { Lack of experience of the } \\
\text { systems' processes and } \\
\text { operations }\end{array}$ & $\begin{array}{l}\text { Knowledge base and experience of the } \\
\text { systems' processes and operations will } \\
\text { develop. Uncertainty will be low within the } \\
\text { system boundaries. }\end{array}$ \\
\hline Forest management & $\begin{array}{l}\text { Lack of predictability of } \\
\text { climate change effects }\end{array}$ & $\begin{array}{l}\text { Cause and effect are indeterminable and } \\
\text { only visible in retrospect, uncertainty } \\
\text { remains high. }\end{array}$ \\
\hline
\end{tabular}

Furthermore, the lack of evidence on clear cause-effect linkages can cause different ways of seeing and perceiving the risks [82]. In the case of forest management, the lack of secured knowledge enhances competing views on management strategies and leads to conflicts of different interest groups. This ambiguity may arise in connection with risk management strategies, but also in connection with how scientific evidence is interpreted [50,82].

To properly address uncertainty and ambiguity in risk management, a debate on the tolerability of risks involving a wide range of experts is a prerequisite. For determining tolerability, not only 
scientific evidence is needed, but societal judgment and shared social values also play a crucial role [81]. Transdisciplinary social-ecological approaches are suitable for triggering debates on tolerability, as well as on the precautionary principle and other possible measures aiming at risk distribution. Finally, a critical assessment of the relevance of risks is required which centers not only on scientific evidence, but also on ethical considerations, addressing the normative dimensions of societal relations to nature and their sustainable transformation.

\section{Conclusions}

In this paper, a social-ecological perspective on risks has been elaborated by drawing on the concepts of societal relations to nature and provisioning systems. Based on four case studies it has been shown that the social-ecological approach enables a holistic view on risks by (a) considering linkages and interdependencies between the involved provisioning systems, (b) unveiling the mode of risk production and (c) combining knowledge from natural and social sciences. As a consequence, the social-ecological perspective broadens the scope for risk management strategies and suggests a reorganization of the involved provisioning systems. By pursuing a transdisciplinary approach involving a wide range of experts and the public, the social-ecological perspective allows for the development of informed risk management strategies.

Acknowledgments: The authors wish to thank Thomas Kluge for his helpful hints and comments. The case studies on pharmaceuticals, microplastics, and semicentralized water infrastructures are based on results accomplished within projects funded by the Federal Ministry of Education and Research (BMBF): "start: Management strategies for pharmaceutical residues in drinking water" (2005-2008; grant number: 07VPS16); "SAUBER+: Innovative concepts for wastewater from public health sector facilities" (2011-2015; grant number 02WRS1280B); "PlastX-Plastics as a systemic risk for social-ecological supply systems" (2015-2021; grant number: 01UU1603A); "Semizentral: Resource-efficient and flexible supply and waste disposal infrastructure systems for rapidly growing cities of the future-Phase 2" (2013-2017; grant number: 02WCL1266G). The case study on forest management was derived from the Senckenberg Biodiversity and Climate Research Centre (BiK-F) which was funded by the Hessian initiative for scientific and economic excellence (LOEWE) from 2008 to 2014.

Author Contributions: Carolin Völker and Johanna Kramm wrote the manuscript, contributed the microplastics example (Section 3.2), the literature review and the conceptual framing. Heide Kerber contributed to the pharmaceuticals example (Section 3.1). Engelbert Schramm contributed to the example of forest management (Section 3.4). Martina Winker contributed to the examples of pharmaceuticals (Section 3.1) and semicentralized water infrastructures (Section 3.3). Martin Zimmermann contributed to the example of semicentralized water infrastructures (Section 3.3). All authors compiled the figures and tables and contributed to the discussion.

Conflicts of Interest: The authors declare no conflict of interest.

\section{References}

1. Neisser, F. 'Riskscapes' and risk management: Review and synthesis of an actor-network theory approach. Risk Manag. 2014, 16, 88-120. [CrossRef]

2. Renn, O. Concepts of risk. An interdisciplinary review. Part 1: Disciplinary risk concepts. GAIA Ecol. Perspect. Sci. Soc. 2008, 17, 50-66. [CrossRef]

3. Renn, O.; Dreyer, M.; Klinke, A.; Schweizer, P.-J. Systemische Risiken: Charakterisierung, Management und Intergration in eine aktive Nachhaltigkeitspolitik. In Jahrbuch Ökologische Ökonomik 5 (Soziale Nachhaltigkeit); Beckenbach, F., Hampicke, U., Leipert, C., Meran, G., Minsch, J., Nutzinger, H.G., Pfriem, R., Weimann, J., Wirl, F., Witt, U., Eds.; Metropolis: Marburg, Germany, 2007; pp. 157-158.

4. Schramm, E.; Lux, A. Klimabedingte Biodiversitätsrisiken. Ein neues Forschungsgebiet für BiK-F; Knowledge Flow Paper, Biodiversität und Klima Forschungszentrum No. 16; LOEWE Biodiversität und Klima Forschungszentrum (BiK-F): Frankfurt am Main, Germany, 2014.

5. Birkmann, J. Regulation and coupling of society and nature in the context of natural hazards. In Coping with Global Environmental Change, Disasters and Security: Threats, Challenges, Vulnerabilities and Risks; Brauch, H.G., Oswald Spring, Ú., Mesjasz, C., Grin, J., Kameri-Mbote, P., Chourou, B., Dunay, P., Birkmann, J., Eds.; Springer: Berlin/Heidelberg, Germany, 2011; pp. 1103-1127.

6. Luhmann, N. Risk. A Sociological Theory; Aldine de Gruyter: New York, NY, USA, 1995.

7. Douglas, M. Risk Acceptability According to the Social Sciences; Sage: New York, NY, USA, 1985. 
8. Eiser, R.; Miles, S.; Frewer, L. Trust, perceived risk and attitudes towards food technologies. J. Appl. Soc. Psychol. 2002, 32, 2423-2434. [CrossRef]

9. Renn, O.; Schweizer, P.-J.; Dreyer, M.; Klinke, A. Risiko. Über den Gesellschaftlichen Umgang mit Unsicherheit; Oekom: München, Germany, 2007.

10. Becker, E.; Jahn, T. (Eds.) Soziale Ökologie. Grundzüge einer Wissenschaft von den Gesellschaftlichen Naturverhältnissen; Campus Verlag: Frankfurt am Main, Germany, 2006.

11. Hummel, D.; Jahn, T.; Schramm, E. Social-Ecological Analysis of Climate Induced Changes in Biodiversity. Outline of a Research Concept; Knowledge Flow Paper, Biodiversität und Klima Forschungszentrum No. 11; LOEWE Biodiversität und Klima Forschungszentrum (BiK-F): Frankfurt am Main, Germany, 2011.

12. Hummel, D.; Jahn, T.; Keil, F.; Liehr, S.; Stieß, I. Social Ecology als Critical, Transdisciplinary Science-Conceptualizing, Analyzing, and Shaping Societal Relations to Nature. Sustainability 2017. submitted.

13. Hampel, J. Different concepts of risk: A challenge for risk communication. Int. J. Med. Microbiol. 2006, 296, 5-10. [CrossRef] [PubMed]

14. Taylor-Gooby, P.; Zinn, J.O. Current directions in risk research: New developments in Psychology and Sociology. Risk Anal. 2006, 26, 397-411. [CrossRef] [PubMed]

15. Haddad, S.; Béliveau, M.; Tardif, R.; Krishnan, K. A PBPK Modeling-Based Approach to Account for Interactions in the Health Risk Assessment of Chemical Mixtures. Toxicol. Sci. 2001, 63, 125-131. [CrossRef] [PubMed]

16. Bedford, T.; Cooke, R. Probabilistic Risk Analysis. Foundations and Methods; Cambridge University Press: Cambridge, UK, 2001.

17. Egner, H.; Pott, A. (Eds.) Geographische Risikoforschung. Zur Konstruktion Verräumlichter Risiken und Sicherheiten; Franz Steiner Verlag: Stuttgart, Germany, 2010.

18. Kasperson, R.E.; Renn, O.; Slovic, P.; Brown, H.S.; Emel, J.; Goble, R.; Kasperson, J.X.; Ratick, S. The Social Amplification of Risk A Conceptual Framework. Risk Anal. 1988, 8, 177-187. [CrossRef]

19. Rohrmann, B.; Renn, O. Risk Perception Research. In Cross-Cultural Risk Perception: A Survey of Empirical Studies; Renn, O., Rohrmann, B., Eds.; Springer: Boston, MA, USA, 2000; pp. 11-53.

20. Tagg, J. Grounds of Dispute. Art History, Cultural Politics and the Discursive Field; University of Minnesota Press: Minneapolis, MN, USA, 1992.

21. Douglas, M.; Wildavsky, A. Risk and Culture. An Essay on the Selection of Technological and Environmental Dangers; University of California Press: Berkeley, CA, USA, 1983.

22. Luhmann, N. Communication and Social Order. Risk: A Sociological Theory; Fourth Printing; Transaction Publishers: New Brunswick, NJ, USA, 2008.

23. Habermas, J. Moral Consciousness and Communicative Action; MIT Press: Cambridge, MA, USA, 1990.

24. Jaeger, C.C.; Webler, T.; Rosa, E.A.; Renn, O. Risk, Uncertainty and Rational Action; Routledge: Oxon, NY, USA, 2001.

25. Beck, U. Risk Society. Towards a New Modernity; Sage Publication: Los Angeles, CA, USA, 2010.

26. Egner, H.; Pott, A. Risiko und Raum: Das Angebot der Beobachtungstheorie. In Geographische Risikoforschung: Zur Konstruktion Verräumlichter Risiken und Sicherheiten; Egner, H., Pott, A., Eds.; Franz Steiner Verlag: Stuttgart, Germany, 2010; pp. 9-31.

27. Aven, T. The risk concept-historical and recent development trends. Reliab. Eng. Syst. Saf. 2012, 99, 33-44. [CrossRef]

28. Renn, O. Concepts of risk: An interdisciplinary review. Part 2: Integrative approaches. GAIA Ecol. Perspect. Sci. Soc. 2008, 17, 196-204. [CrossRef]

29. Kasperson, R.E.; Renn, O.; Slovic, P.; Kasperson, J.X.; Emani, S. Social amplification of risk: The media and public response. In Waste Processing, Transportation, Storage and Disposal, Technical Programs and Public Education. Volume 1: High-Level Waste and General Interest; Post, R.G., Ed.; Arizona Board of Regents: Tucson, AZ, USA, 1989; pp. 131-135.

30. WBGU-German Advisory Council on Global Change. World in Transition. Strategies for Managing Global Environmental Risks: Annual Report 1998; German Advisory Council on Global Change: Heidelberg, Germnay, 2000.

31. International Risk Governance Council. An Introduction to the IRGC Risk Governance Framework; IRGC: Geneva, Switzerland, 2007. 
32. Millstone, E. Science, risk and governance: Radical rhetorics and the realities of reform in food safety governance. Res. Policy 2009, 38, 624-636. [CrossRef]

33. Hummel, D.; Kluge, T. Regulationen. In Soziale Ökologie: Grundzüge einer Wissenschaft von den Gesellschaftlichen Naturverhältnissen; Becker, E., Jahn, T., Eds.; Campus Verlag: Frankfurt am Main, Germany, 2006; pp. 248-258.

34. Tabak, H.H.; Bunch, R.L. Steroid hormones as water pollutants. I. Metabolism of natural and synthetic ovulation-inhibiting hormones by microorganisms of activated sludge and primary settled sewage. Dev. Ind. Microbiol. 1970, 11, 367-376.

35. Norpoth, K.; Nehrkorn, A.; Kirchner, M.; Holsen, H.; Teipel, H. Untersuchungen zur Frage der Löslichkeit und Stabilität ovulationshemmender Steroide in Wasser, Abwässern und belebtschlamm. Z. Bakteriol. Mikrobiol. Hyg. 1973, 156, 500-511.

36. Hignite, C.; Azarnoff, D.L. Drugs and drug metabolites as environmental contaminants: Chlorophenoxyisobutyrate and salicylic acid in sewage water effluent. Life Sci. 1977, 20, 337-341. [CrossRef]

37. Garrison, A.W.; Pope, J.D.; Allen, F.R. GC/MS analysis of organic compounds in domestic wastewaters. In Identification and Analysis of Organic Pollutants in Water; Ann Arbor Sicence Publisher Sicence Publisher, Inc.: Ann Arbor, MI, USA, 1976; pp. 517-556.

38. Heberer, T. Occurrence, fate, and removal of pharmaceutical residues in the aquatic environment: A review of recent research data. Toxicol. Lett. 2002, 131, 5-17. [CrossRef]

39. Fent, K.; Weston, A.A.; Caminada, D. Ecotoxicology of human pharmaceuticals. Aquat. Toxicol. 2006, 76, 122-159. [CrossRef] [PubMed]

40. Weber, F.; Bergmann, A.; Hickmann, S.; Ebert, I.; Hein, A.; Küster, A. Pharmaceuticals in the environment-Global occurrences and perspectives. Environ. Toxicol. Chem. 2015, 34, 823-835.

41. Webb, S.; Ternes, T.; Gibert, M.; Olejniczak, K. Indirect human exposure to pharmaceuticals via drinking water. Toxicol. Lett. 2003, 142, 157-167. [CrossRef]

42. Keil, F.; Bechmann, G.; Kümmerer, K.; Schramm, E. Systemic risk governance for pharmaceutical residues in drinking water. GAIA Ecol. Perspect. Sci. Soc. 2008, 17, 355-361. [CrossRef]

43. Brandmayr, C.; Kerber, H.; Winker, M.; Schramm, E. Impact assessment of emission management strategies of the pharmaceuticals Metformin and Metoprolol to the aquatic environment using Bayesian networks. Sci. Total Environ. 2015, 532, 605-616. [CrossRef] [PubMed]

44. Thompson, R.C.; Olsen, Y.; Mitchell, R.P.; Davis, A.; Rowland, S.J.; John, A.W.G.; McGonigle, D.; Russell, A.E. Lost at sea: Where is all the plastic? Science 2004, 304, 838. [CrossRef] [PubMed]

45. Van Cauwenberghe, L.; Vanreusel, A.; Mees, J.; Janssen, C.R. Microplastic pollution in deep-sea sediments. Environ. Pollut. 2013, 182, 495-499. [CrossRef] [PubMed]

46. Mani, T.; Hauk, A.; Walter, U.; Burkhardt-Holm, P. Microplastics profile along the Rhine river. Sci. Rep. 2015, 5, 17988. [CrossRef] [PubMed]

47. Cole, M.; Lindeque, P.; Halsband, C.; Galloway, T.S. Microplastics as contaminants in the marine environment: A review. Mar. Pollut. Bull. 2011, 62, 2588-2597. [CrossRef] [PubMed]

48. Derraik, J.G.B. The pollution of the marine environment by plastic debris: A review. Mar. Pollut. Bull. 2002, 44, 842-852. [CrossRef]

49. Jambeck, J.R.; Geyer, R.; Wilcox, C.; Siegler, T.R.; Perryman, M.; Andrady, A.; Narayan, R.; Law, K.L. Plastic waste inputs from land into the ocean. Science 2015, 347, 768-771. [CrossRef] [PubMed]

50. Kramm, J.; Völker, C. Understanding risks of microplastics: A social-ecological risk perspective. In Freshwater Microplastics: Emerging Contaminants? Wagner, M., Lambert, S., Eds.; Springer: New York, NY, USA, 2017; in press.

51. Von Moos, N.; Burkhardt-Holm, P.; Köhler, A. Uptake and effects of microplastics on cells and tissue of the blue mussel Mytilus edulis L. after an experimental exposure. Environ. Sci. Technol. 2012, 46, 11327-11335. [CrossRef] [PubMed]

52. Van Cauwenberghe, L.; Janssen, C.R. Microplastics in bivalves cultured for human consumption. Environ. Pollut. 2014, 193, 65-70. [CrossRef] [PubMed]

53. Duis, K.; Coors, A. Microplastics in the aquatic and terrestrial environment: Sources (with a specific focus on personal care products), fate and effects. Environ. Sci. Eur. 2016, 28, 1. [CrossRef] [PubMed] 
54. Dris, R.; Imhof, H.; Sanchez, W.; Gasperi, J.; Galgani, F.; Tassin, B.; Laforsch, C. Beyond the ocean: Contamination of freshwater ecosystems with (micro-) plastic particles. Environ. Chem. 2015, 12, 539-550. [CrossRef]

55. Federal Institute for Risk Assessment. Mikroplastikpartikel in Lebensmitteln. Stellungnahme Nr. 013/2015. 2015. Available online: http://www.bfr.bund.de/cm/343/mikroplastikpartikel-in-lebensmitteln.pdf (accessed on 30 May 2017).

56. Girard, N.; Lester, S.; Paton-Young, A.; Saner, M. Microbeads: "Tip of the Toxic Plastic-berg"? Regulation, Alternatives, and Future Implications; Institute for Science, Society and Policy: Ottawa, ON, Canada, 2016.

57. Ballance, A.; Ryan, P.G.; Turpie, J.K. How much is a clean beach worth? The impact of litter on beach users in the Cape Peninsula, South Africa. S. Afr. J. Sci. 2000, 96, 210-230.

58. Free, C.M.; Jensen, O.P.; Mason, S.A.; Eriksen, M.; Williamson, N.J.; Boldgiv, B. High-levels of microplastic pollution in a large, remote, mountain lake. Mar. Pollut. Bull. 2014, 85, 156-163. [CrossRef] [PubMed]

59. Jang, Y.C.; Hong, S.; Lee, J.; Lee, M.J.; Shim, W.J. Estimation of lost tourism revenue in Geoje Island from the 2011 marine debris pollution event in South Korea. Mar. Pollut. Bull. 2014, 81, 49-54. [CrossRef] [PubMed]

60. Der Spiegel. Plastikteilchen Verunreinigen Lebensmittel. Unterschätzte Gefahr, 2013. 17 November 2013. Available online: http://www.spiegel.de/wissenschaft/technik/winzige-plastikteile-verunreinigenlebensmittel-a-934057.html (accessed on 30 September 2016).

61. NDR. Mikroplastik in Mineralwasser und Bier. 2014. Available online: http://www.ndr. de/ratgeber/verbraucher/Mikroplastik-in-Mineralwasser-und-Bier,mikroplastik134.html (accessed on 30 September 2016).

62. Federal Institute for Risk Assessment. BfR Consumer Monitor 02 | 2016; Federal Institute for Risk Assessment: Berlin, Germany, 2016.

63. Renn, O. The Role of Risk Perception for Risk Management. Reliab. Eng. Syst. Saf. 1998, 59, 49-62. [CrossRef]

64. Winker, M.; Schramm, E.; Schulz, O.; Zimmermann, M.; Liehr, S. Integrated water research and how it can help address the challenges faced by Germany's water sector. Environ. Earth Sci. 2016, 75, 1226. [CrossRef]

65. Otterpohl, R.; Albold, A.; Oldenburg, M. Source control in urban sanitation and waste management: Ten systems with reuse of resources. Water Sci. Technol. 1999, 39, 153-160. [CrossRef]

66. Larsen, T.A.; Alder, A.C.; Eggen, R.I.L.; Maurer, M.; Lienert, J. Source separation: Will we see a paradigm shift in wastewater handling? Environ. Sci. Technol. 2009, 43, 6121-6125. [CrossRef] [PubMed]

67. Schramm, E.; Kerber, H.; Trapp, J.H.; Zimmermann, M.; Winker, M. Novel urban water systems in Germany: Governance structures to encourage transformation. Urban Water J. 2017. accepted for publication.

68. Birkmann, J. Measuring vulnerability to promote disaster-resilient societies: Conceptual frameworks and definitions. In Measuring Vulnerability to Natural Hazards: Towards Disaster Resilient Societies; Birkmann, J., Ed.; United Nations University Press: New Delhi, India, 2006; pp. 7-54.

69. Sutmöller, J.; Spellmann, H.; Fiebiger, C.; Albert, M. Der Klimawandel und seine Auswirkungen auf die Buchenwälder in Deutschland The effects of climate change on beech forests in Germany. Ergeb. Angew. Forsch. Buche 2008, 3, 135.

70. Yousefpour, R.; Jacobsen, J.B.; Thorsen, B.J.; Meilby, H.; Hanewinkel, M.; Oehler, K. A review of decision-making approaches to handle uncertainty and risk in adaptive forest management under climate change. Ann. For. Sci. 2012, 69, 1-15. [CrossRef]

71. Hanewinkel, M.; Cullmann, D.A.; Schelhaas, M.-J.; Nabuurs, G.-J.; Zimmermann, N.E. Climate change may cause severe loss in the economic value of European forest land. Nat. Clim. Chang. 2013, 3, $203-207$. [CrossRef]

72. Kromp-Kolb, H.; Lindenthal, T.; Bohunovsky, L. Österreichischer Sachstandsbericht Klimawandel 2014. GAIA Ecol. Perspect. Sci. Soc. 2014, 23, 363-365.

73. Schramm, E.; Holland, V. Climate change management in Central European forestry and the perspective of risk sharing. For. Policy 2017. submitted.

74. Schramm, E. Gesellschaftliche Wahrnehmung klimabedingter Biodiversitätsveränderungen in der Forstwirtschaft. In Klimawandel und Biodiversität: Folgen für Deutschland; Mosbrugger, V., Brasseur, G.P., Schaller, M., Eds.; WBG Wissenschaftliche Buchgesellschaft: Darmstadt, Germany, 2012; pp. 374-376.

75. Yousefpour, R.; Hanewinkel, M. Forestry professionals' perceptions of climate change, impacts and adaptation strategies for forests in south-west Germany. Clim. Chang. 2015, 130, 273-286. [CrossRef] 
76. Schramm, E.; Litschel, J. Stakeholder-Dialoge-Ein Instrument zur Bearbeitung von Konflikten um Biodiversität in mitteleuropäischen Wäldern. Nat. Landsch. 2014, 478-482. [CrossRef]

77. Perrow, C. Normal Accidents. Living with High Risk Technologies; Princeton University Press: Princeton, NJ, USA, 1999.

78. Klinke, A.; Renn, O. Systemic risks as challenge for policy making in risk governance. Forum Qual. Soc. Res. 2006, 7, Art.33. Available online: http://www.qualitative-research.net/index.php/fqs/article/viewArticle/ 64/131 (accessed on 30 May 2017).

79. Beisheim, M.; Rudloff, B.; Ulmer, K. Risiko-Governance. Umgang Mit Globalen und Vernetzten Risiken; SWP Berlin: Berlin, Germany, 2012; Volume 8.

80. Suda, M.; Pukall, K. Multifunktionale Forstwirtschaft zwischen Inklusion und Extinktion (Essay). Schweiz. Z. Forstwes. 2014, 165, 333-338. [CrossRef]

81. Klinke, A.; Renn, O. A new approach to risk evaluation and management: Risk-based, precaution-based, and discourse-based strategies. Risk Anal. 2002, 22, 1071-1094. [CrossRef] [PubMed]

82. Shaxson, L. Structuring policy problems for plastics, the environment and human health: Reflections from the UK. Philos. Trans. R. Soc. B Biol. Sci. 2009, 364, 2141-2151. [CrossRef] [PubMed]

(C) 2017 by the authors. Licensee MDPI, Basel, Switzerland. This article is an open access article distributed under the terms and conditions of the Creative Commons Attribution (CC BY) license (http://creativecommons.org/licenses/by/4.0/). 